\title{
*Çocukların Eğitiminde Merkezi Sınav Başarısı ile İlgili Dersler Daha mı Önemli? Aile Görüşü ve İlişkili Faktörler
}

\section{Are School Courses Related to Central Exam Success More Important in Children's Education? Parental View and Related Factors \\ Gülfem Dilek YURTTAȘ KUMLU*, Rahime COBANOĞLU**}

• Geliş Tarihi: 07.05.2019 • Kabul Tarihi: 28.10.2019 • Çevrimiçi Yayın Tarihi: 28.10.2019

\section{$\ddot{O} \mathbf{z}$}

Ailelerin çocuklarının eğitimi üzerindeki belirleyici etkisi göz önünde bulundurularak, bu çalışmada ailelerin merkezi sınav başarısı ile ilgili olan (Fen Bilimleri, Matematik, Sosyal Bilgiler, Türkçe ve Yabanc1 Dil) ve ilgili olmayan (Beden Eğitimi, Etik, Sanat) dersleri ne kadar önemli gördükleri incelenmektedir. Bu çalışmada özelikle velilerin merkezi sınav başarısı ile ilgili olan ve olmayan bir dersi önemli görmeleri ile velilerin eğitim düzeyi, gelir seviyesi ve çocuğunun öğretim düzeyi arasındaki ilişki araştırılmıştır. Çalışmaya Sinop ilinin merkez ilçelerinden 540 veli katılmıştır. Veri analizinde betimsel istatistiklere ve lojistik regresyon analizine başvurulmuştur. Bulgular, velilerin birçoğu tarafindan Matematik dersinin çocukların eğitimi için en önemli ders olarak görüldüğünü göstermiştir. Beden Eğitimi, Sanat ve Sosyal Bilgiler dersleri ise çok az sayıdaki veli tarafindan çocukların eğitiminde birinci sırada önemli görülmüştür. Lojistik regresyon analizi sonuçları, velilerin merkezi sınav başarısı ile ilgili olan ve ilgili olmayan bir dersi önemli görmeleri ile velinin eğitim düzeyi ve çocuğunun öğretim düzeyi arasında anlamlı bir ilişki olduğunu göstermiştir. Çalışma bulguları, merkezi sınavların ve ailenin Türk Eğitim Sistemi üzerindeki etkisi göz önünde bulundurularak tartışılmıştır.

Anahtar sözcükler: aile görüşleri, derslere verilen önem, merkezi sınav başarısı

Atıf:

Yurttaş Kumlu, G., ve Çobanoğlu, R. (2019). Çocukların eğitiminde merkezi sınav başarısı ile ilgili dersler daha mı önemli? Aile görüşü ve ilişkili faktörler. Pamukkale Üniversitesi Ĕgitim Fakültesi Dergisi, 49, 375-392. doi: 10.9779/pauefd.561551.

\footnotetext{
* Dr. Araştırma Gör., Sinop Üniversitesi, Eğitim Fakültesi, Matematik ve Fen Bilimleri Eğitimi Bölümü, gdyurttas@gmail.com, https://orcid.org/ 0000-0003-4741-2654

* Dr. Öğr. Üyesi, Sinop Üniversitesi, Eğitim Fakültesi, Eğitim Bilimleri Bölümü, crahime@gmail.com, https://orcid.org/0000-0003-4662-8920
} 


\begin{abstract}
The present study, considering the influence of parents on the education of their children, examines how parents rate the importance of courses that are related (Science, Mathematics, Social Studies, Turkish, and Foreign Language Education) and not related (Physical Education, Ethics, Art) to central exam success. Specifically, the study investigated the relationship between parents' perception of the importance of a subject that is related and not related to central exam success and parents' educational degree and income level, and their children's level of education. The study involved 540 parents from the central districts of Sinop. Descriptive statistics and logistic regression analysis were used in data analysis. Findings revealed that most of the parents perceived Mathematics as the most important subject for the education of their children. However, a few parents ranked Physical Education, Art, and Social Studies courses as the most important subject for children's education. The logistic regression analysis showed that there was a significant relationship between the parents' perception of the importance of subjects that are related or not related to central exam success and parents' degree of education and children's level of education. The study findings were discussed given the influence of central exams and parents on Turkish Education System.
\end{abstract}

Keywords: parental views, importance of school courses, central exam success

\title{
Cited:
}

Yurttaş Kumlu, G., \& Çobanoğlu, R. (2019). Are school courses related to central exam success more important in children's education? Parental view and related factors. Pamukkale Üniversitesi Eğitim Fakültesi Dergisi, 49, 375-392. doi: 10.9779/pauefd.561551. 


\section{Giriș}

Ekolojik sistemler kuramına göre bireyin gelişimini belirleyen temel faktörlerden birisi ailedir (Bronfenbrenner, 1979). Bu bağlamda, alanyazında aile ile ilişkili çeşitli etmenlerin çocukların gelişimi üzerindeki etkisine yönelik çok sayıda çalışmaya rastlanmaktadır. Geleneksel olarak, bu çalışmalarda ailenin yaşadığı bölge, sosyo-ekonomik durumu, dini, etnik kökeni, iş yaşantısı ve sahip olduğu sosyal destek ile çocuk gelişimi arasındaki ilişki araştırmacıların dikkatini çekmiştir (Bronfenbrenner, 1986). Aileler ile yapılan çalışmalarda ele alınan temel konulardan bir diğeri, ailelerin çocuklarının eğitimine ilişkin görüşleri ve uygulamalarıdır. Bu kapsamda yürütülen çalışmalarda ön plana çıkan ana değişkenler arasında eğitimde aile katılımı (örneğin, Curry ve Holter, 2019; Epstein, 1986; Hoover-Dempsey ve Sandler, 1995), ailenin çocuğuna yönelik beklentileri (örneğin, Davis-Kean, 2005; Halle, Kurtz-Costes ve Mahoney,1997; Nacak, Yağmurlu, Durgel ve van de Vijver, 2011; Neuenschwander, Vida, Garrett ve Eccles, 2007), ailenin çocuklarının eğitimi ile ilgili istekleri/hayalleri (örneğin, Archer vd., 2013; Spera, Wentzel ve Matto, 2009; Wentzel, 1998) ve ailenin çocuğun becerilerine yönelik inançları (örneğin, Galper, Wigfield ve Seefeldt, 1997) yer almaktadır.

$\mathrm{Bu}$ çalışmada Sinop ili örneğinde ailelerin çocuklarının eğitiminde hangi dersleri daha önemli gördükleri sorusu ele alınmaktadır. Araştırmanın odağında velilerin merkezi sınav başarısı ile ilgili olan ve ilgili olmayan çeşitli derslere önem verme durumları ile velilerin eğitim düzeyi, gelir seviyesi ve çocuğunun öğretim düzeyi değişkenleri arasındaki ilişki yer almaktadır. $\mathrm{Bu}$ araştırma sorusu beklenti-değer kuramına dayanmaktadır. Bu motivasyon kuramında öne çıkan argümanlardan birisi çocukların değerli gördükleri etkinlikleri yerine getirmek için daha istekli ve 1srarlı olmalarıdır (Wigfield, 1994; Wigfield ve Eccles, 2000). Çocukların nelere değer verdiklerini etkileyen ana faktörlerden birisi Eccles ve arkadaşlarının geliştirdikleri modele göre ailelerdir. Bu modele göre, genetik yapı, eğitim geçmişi, üyesi olunan kültür, meslek ve gelir gibi kimi özelliklere bağlı olarak şekillenen aile inançları ve davranışları, çocukların neleri başarmayı değerli gördüklerini etkilemektedir. Ailelerinin etkisiyle çocukların geliştirdiği inançlar, onların hangi etkinliklere katılacağını ve başarılarını belirlemektedir (Eccles, 2005). $\mathrm{Bu}$ modeli doğrulayan bir çalışmada, Simpkins, Fredricks ve Eccles (2012), annelerin spor, müzik ve matematiğe yönelik görüşlerinin çocuklarının bu derslere yönelik motivasyonlarını etkilediğini ve annelerinin etkisiyle çocukların geliştirdikleri motivasyon düzeyinin onların dört yıl sonra spor ve müzik için ayırdıkları zamanı ve lisede matematik dersini seçme durumlarını etkilediğini ortaya koymuştur.

Ailelerin bazı dersleri önemli görmeleri çocuklarının bu derslere yönelik ilgilerini arttırabilir. Diğer taraftan, Eccles ve Wigfield (2002) tarafından ileri sürüldügü gibi çocuklar bireysel olarak ilgi duymasalar bile bazı dersleri sadece ailelerini memnun etmeye yarayacağını düşündükleri için önemseyebilirler. Bireyin isteklerinden çok ailenin isteklerini ön planda tutan ve aileye karşı sadakate değer veren geleneksel Türk aile yapısında (Sunar ve Okman-Fişek, 2005) çocuk üzerindeki aile etkisinin çok daha büyük olabileceği iddia edilebilir. Türk aile yapısında aile görüşlerinin eğitim süreçlerinde çocukların motivasyonlarını ve davranışlarını önemli ölçüde şekillendireceği göz önünde bulundurulursa, Türkiye bağlamında ailelerin çocuklarının eğitiminde hangi dersleri öncelikli olarak önemli bulduklarının ortaya konulmasına ihtiyaç olduğu düşünülmektedir. 
Sonuç olarak, ailelerin merkezi sınav başarısı ile ilgili olan ve olmayan çeşitli derslere önem verme durumlarının ve bununla ilişki faktörlerin araştırıldığ 1 bu çalışma, üç ana nedenle önemli görülmektedir. Birincisi, günümüzde eğitimde kalite göstergelerinden birisi farklı paydaşların görüşlerinin alınmasıdır. Aileler, hiç şüphesiz eğitimin en önemli paydaşlarından birisidir ve bu çalışma ailelerin önem verdikleri dersleri ortaya koyarak onların eğitim ile ilgili beklentilerinin anlaşılmasına katkı sağlamaktadır. Çalışma bulguları, ailelerin eğitime yönelik beklentileri çerçevesinde mevcut eğitim sisteminin değerlendirilmesine olanak sağlayabilir. Ailelerin önemsedikleri konular, eğitim sistemimizde nelerin önemsendiği ve nelerin önemsenmesi gerektiği hakkında yapılacak tartışmalara yol gösterebilir. İkincisi, alanyazında belirtildiği üzere aileler, çocuklarını daha çok önem verdikleri derslere yönlendirebilirler ve çocuklarını bu alanlarda daha çok destekleyebilirler. Bu çalışma, ailelerin önem verdikleri derslere dayalı olarak eğitimdeki potansiyel yönelimler ve bu yönelimlerin çocuklar açısından sonuçları hakkında çıkarımlarda bulunulmasını sağlayabilir. Üçüncü ve son olarak, bu çalışmada ailelerin derslere verdikleri önem ile aile eğitim düzeyi, gelir seviyesi ve çocuğun öğretim düzeyi arasındaki ilişki araştırılmaktadır. Ailelerin eğitime yönelik bakış açısının hangi etkilere bağlı olarak farklılaştığını ortaya koymak, onların eğitime ilişkin düşüncelerinin nasıl şekillendiğinin anlaşılması için önemli görülmektedir.

\section{Ailelerin Eğitime Yönelik Görüșleri}

Ailelerin eğitime ilişkin önemsedikleri konuların başında çocuklarının okullarda yüksek akademik başarı elde etmeleri gelmektedir (Burgess, Greaves, Vignoles ve Wilson, 2014; Rubie-Davies, Peterson, Irving, Widdowson ve Dixon, 2010; Schneider ve Buckley, 2002). Ancak Coldron ve Boulton (1991), ailelerin eğitim ile ilgili beklentilerinin akademik standartların karşılanması ile sınırlı olmadığını ve ailelerin okullarda çocuklarının güvende ve mutlu olmalarını da önemsediklerini vurgulamıştır. Çinli ailelerden oluşan bir örneklem ile yapılan bir çalışmada, aileler eğitimin önemine değinirken eğitimin çocukların gelişimine, ahlaki değerlerin ögretimine ve topluma uyum sağlanmasına yaptığı katkılardan bahsetmişlerdir (Francis ve Archer, 2005).

Ryan, Casas, Kelly-Vance, Ryalls ve Nero (2010), Latin kökenli olan ailelerin eğitimde sosyal başarı kazanımını en az akademik başarı kazanımı kadar önemsediklerini ve hatta Latin kökenli olmayan Amerikan ailelerin çocuklarından beklentilerinin akademik başarıdan daha çok sosyal başarı olduğunu göstermişlerdir. Okagaki ve Sternberg (1993), okullarda çocuklara kazandırılması gereken davranışlara yönelik aile görüşlerini incelemişlerdir. $\mathrm{Bu}$ çalışmada ailelerin birinci ve ikinci sınıf çocuklarına konformizm gerektiren davranışların (yönergeleri takip etme, okul kurallarına uyma) öğretimini bağımsızlık gerektiren davranışların (karar alma, arkadaşlık kurma) öğretiminden daha önemli buldukları ortaya konmuştur. Amerika'da doğmuş çocukların aileleri tarafından çocuklarının akademik düşünme becerilerini kazanmaları düzgün bir şekilde yazmayı öğrenmelerinden daha önemli bulunurken, göçmen aileler tarafindan akademik kazanımların yanı sıra çocuklarının tertipli ve düzenli çalışmayı öğrenmeleri önemli görülmüsstür. Bu bulgular kültürün ve göçmenliğin ailelerin çocuklara okullarda kazandırılması gereken hususlar hakkındaki görüşlerini etkilediğini göstermektedir.

Ailelerin çocuklarının eğitiminde önem verdikleri konuları belirleyen etmenler arasında ailenin gelir seviyesi ve eğitim düzeyi de yer almaktadır. Örneğin, Amerika'da yürütülen bir çalışmada, çocukları dezavantajlı okullara devam eden aileler tarafından akademik başarı 
getiren öğretmenlerin öğrenci memnuniyetini sağlayan öğretmenlerden daha çok tercih edildiği fakat avantajlı okullara devam eden çocukların aileleri için bu durumun ters yönde olduğu belirtilmiştir (Jacob ve Lefgren, 2007). Schneider, Marschall, Teske ve Roch (1998) düşük düzeyde eğitime sahip olan ailelerin yüksek düzeyde eğitime sahip olan ailelere kıyasla, çocuklarının iyi bir üniversiteye ve iyi bir işe sahip olmaları için standart test başarısı odaklı bir eğitime daha çok değer verdiklerini ortaya koymuşlardır. Schneider ve arkadaşlarının bu çalışmasında ayrıca çocukları için özel okul seçen ailelerin değerler eğitiminin önemini daha çok vurguladıkları belirtilmiştir. Türkiye örnekleminde, Saçkes (2013) üst sosyo-ekonomik seviyedeki ailelerin okul öncesi dönemde çocukların sosyal duygusal gelişimine alt ve orta sosyo-ekonomik seviyedeki ailelerden daha fazla önem verdiklerini göstermiştir. Yine Türkiye örneğinde, Saçkes (2014) okul öncesi eğitimde okuma, yazma ve matematik eğitimini daha önemli gören ailelerin, okul öncesi eğitimde etik ve sanatı daha önemli gören ailelere kıyasla, daha düşük bir eğitim düzeyine ve daha düşük bir gelir seviyesine sahip oldukları bulgusuna ulaşmıştır. Ayrıca Saçkes (2014) bu çalışmasında çocuğunun yaşının ailelerin önemli gördükleri alanları etkilediğini de ortaya koymuştur. Okul öncesi eğitimde okuma, yazma ve matematik eğitimini daha önemli gören ailelerin okul öncesi eğitimde etik ve sanatı daha önemli gören ailelere kıyasla, yaşça daha büyük bir çocuğa sahip oldukları bulunmuştur.

Türk Eğitim Sistemi’nde öğrencilerin geleceğini merkezi sınavların belirlediği yaygın bir kanıdır. Türkiye'de medya organlarında yer bulmuş olan "TEOG Anneleri” tanımlaması, merkezi sınav başarısına kimi aileler tarafından verilen önem derecesinin ne kadar yüksek olabileceğini göstermektedir. Senler ve Sungur (2009) da Türk Eğitim Sistemi'ni rekabet ve test odaklı olarak tanımlamış ve böyle bir sistemde gelecekte daha iyi hayat standartlarına kavuşmak için aileler ve çocukları için merkezi sınavlardan yüksek başarı elde etmenin önemli bir hedef haline geldiğine değinmişlerdir. Sınav odaklı eğitim sisteminin etkilerinin okul öncesi eğitimde bile hissedildiği iddia edilebilir. Achhpal, Goldman ve Rohner'ın (2007) çalışmasında iki farklı etnik kökene mensup Amerikalı aileler tarafından okul öncesi eğitimde çocuklara kazandırılması gereken en önemli yetkinlik sosyal beceriler ve davranışlar olarak belirlenmiş olsa da Saçkes'in (2014) çalışmasında Türk ailelerin \%21'i okul öncesi eğitimde en önemli konu alanı olarak okumaya hazırlığ̣ ve \%18'i yazmaya hazırlığı seçmiştir. Okul öncesi dönemde ailelerin ancak \%1,4'ü tarafından sosyal bilimler birinci sırada önemli görülürken, okul öncesi çocukları olan ailelerin $\% 5,4$ 'ü tarafından sanat en önemli konu alanı olarak seçilmiştir.

\section{Yöntem}

\section{Araştırma Deseni}

$\mathrm{Bu}$ çalışmada ilişkisel araştırma yöntemi kullanılmıştır. İlişkisel araştırmalarda herhangi bir müdahale yapılmadan iki ya da daha fazla değişken arasındaki ilişki incelenmektedir (Fraenkel ve Wallen, 2006). Bu tür araştırmalardan elde edilen bulgular neden-sonuç olarak yorumlanmamalıdır. Bu çalışmada, velilerin merkezi sınav başarısı ile ilgili olan ve olmayan derslere önem verme durumu, velilerin eğitim düzeyi ve gelir seviyesi ile çocuğun öğretim düzeyi değişkenleri ele alınmıştır. Spesifik olarak, bu araştırmada şu sorulara cevap verilmeye çalışılmaktadır: 
1. Velilerin Beden Eğitimi, Etik Fen, Matematik, Sanat, Sosyal Bilgiler, Türkçe ve Yabancı Dil dersleri arasında çocuklarının eğitimi için birinci sırada önemli gördükleri ders hangisidir?

a. Velilerin merkezi sınav başarısı ile ilgili olan bir dersi (Fen, Matematik, Sosyal Bilgiler, Türkçe ve Yabanc1 Dil) ve ilgili olmayan bir dersi (Beden Eğitimi, Etik ve Sanat) birinci sırada önemli görme oranı nedir?

2. Velilerin eğitim düzeyi, gelir seviyesi ve çocuğunun öğretim düzeyi, onların merkezi sınav başarısı ile ilgili olan ve ilgili olmayan bir dersi birinci sırada önemli görme durumunu ne kadar iyi yordamaktadır?

\section{Çalışma Grubu}

Bu araştırmanın çalışma grubunu, Türkiye'de Sinop ilinde okul öncesi, ilkokul (1.- 4. sınıf) ve ortaokul (5.- 8. sınıf) düzeyinde öğrenim gören çocukları olan veliler oluşturmaktadır. Velilerin seçiminde seçkisiz küme örneklem yöntemi kullanılmıştır. Bu çalışma Sinop Üniversitesi İnsan Araştırmaları Etik Kurulunun 15/01/2018 Tarihli 2018/02 say1l onay kararından sonra düzenlenmiştir. $\mathrm{Bu}$ kapsamda ilk aşamada okullar belirlenmiştir. Öğrenci sayısı ve şehir merkezine uzaklığ 1 dikkate alınarak 3 bağımsız anaokulu, 5 ilkokul ve 4 ortaokul seçilmiştir. İkinci aşamada, belirlenen okulların her bir sınıf seviyesinden rastgele iki şube seçilerek anket formu 1392 veliye gönderilmiştir. Bu velilerden \%39'u anketi tamamlamıştır. Çalışmaya toplamda 540 aile katılmıştır. Araştırmaya katılan velilerin özellikleri Tablo 1'de sunulmaktadır.

Tablo 1. Velilerin Özellikleri $(\mathbf{N}=\mathbf{5 4 0})$

\begin{tabular}{lcc}
\hline Değişkenler & $n$ & $\%$ \\
\hline Velinin çocuğa yakınlık derecesi & & \\
Anne & 358 & 66.3 \\
Baba & 165 & 30.6 \\
Eğitim düzeyi & & \\
$\quad$ Lise altı & 141 & 26.1 \\
Lise & 136 & 25.2 \\
$\quad$ Yükseköğretim & 257 & 47.6 \\
Aylık gelir seviyesi & & \\
$\quad$ Düşük gelir seviyesi (<3500 TL) & 255 & 47.2 \\
Orta gelir seviyesi (3501 TL -5500 TL) & 125 & 23.1 \\
$\quad$ Yüksek gelir seviyesi (> 5501 TL) & 135 & 25.0 \\
Çocuğunun öğretim düzeyi & & \\
$\quad$ Okul öncesi eğitim & 112 & 20.7 \\
$\quad$ İlkokul & 254 & 47 \\
Ortaokul & 174 & 32.2 \\
\hline
\end{tabular}

Not. Kayıp veriler bu tabloda gösterilmemiştir.

Tablo 1 incelendiğinde çalışmaya katılan velilerin \%66.3'ünün anne ve \%30.6'sının baba olduğu görülmektedir. Katılımcıların \%26.1'i lise düzeyinin altında, \%25.2'si lise düzeyinde ve \%47.6's1 yükseköğretim düzeyinde bir eğitim derecesine sahiptir. Çalışmaya çeşitli gelir seviyesinden veliler katılmıştır. Velilerin \%47.2'sinin aylık geliri 3500 TL'den az olmakla birlikte, \%23.1'inin aylık geliri 3501 TL ile 5500 TL arasında değişmektedir. Aylık geliri 5501 TL'den yüksek olan velilerin oranı ise \%25'tir. Velilerin \%20.7'sinin çocuğu okul öncesi 
eğitim, \%47'sinin çocuğu ilkokul ve \%32.2'sinin çocuğu ortaokul düzeyinde öğrenim görmektedir.

\section{Veri Toplama Aracı}

Veriler, Saçkes (2014) tarafından geliştirilen bir anket aracılığıyla toplanmıştır. Saçkes (2014) tarafindan belirtildiği üzere, bu anket önceki araştırmalara ve uzman görüşlerine dayalı olarak geliştirilmiştir. Ayrıca, Saçkes (2014) anketin görünüş ve kapsam geçerliğini sağlamak için eğitim programları ve öğretim, okul öncesi eğitimi ve psikoloji alanlarında lisansüstü eğitime sahip uzmanların görüşlerine başvurmuş ve bu anket için 10 aile ile bir pilot çalışması gerçekleştirmiştir. Saçkes (2014), bu anketi okul öncesi eğitim düzeyinde öğrenim gören çocukları olan ailelerin akademik alanlara verdikleri önemi belirlemek için geliştirmiştir. Bu çalışma farklı öğretim düzeyinde çocukları olan aileleri kapsadığı için anketin içeriğinde bazı değişikliklerin yapılması gerekli görülmüştür. Saçkes'in anketi, okul öncesi eğitime uygun olacak şekilde Etik ve Ahlak, Fen Bilimleri, İkinci Dil, Matematik, Sanat, Sosyal Bilgiler, Okumaya Hazırlık ve Yazmaya Hazırlık alanlarından oluşmaktadır. Bu çalışmada kullanılan ankette Okumaya Hazırlık ve Yazmaya Hazırlık alanları, anketin okul öncesi eğitim dışında öğrenim gören çocukların aileleri için de uygun olabilmesi için Türkçe olarak ifade edilmiştir. Ayrıca, Saçkes' in anketinde yer almayan ancak eğitim ve öğretim programlarımızda yer alan Beden Eğitimi dersi ankete eklenmiştir. Bu düzenlenmiş anket, kapsam geçerliliği için iki eğitim programları ve öğretim uzmanı tarafından incelenmiştir. Anketin anlaşılırlığı için farklı eğitim derecesine sahip altı veliden görüş alınmıştır.

Anket iki bölümden oluşmaktadır. Anketin ilk bölümü velinin eğitim düzeyi, gelir seviyesi ve çocuğunun öğretim düzeyi ile ilgili sorulardan oluşmaktadır. İkinci bölümde, "Çocuğunuzun sınıfında aşağıdaki alanlardan hangisi öncelikli olarak ele alınmalıdır?" sorusu yer almaktadır. Bu kapsamda velilerden çocukları için önemli gördükleri üç dersi önem derecesine göre sıralamaları istenmiştir (1: En önemli ders, 2: İkinci sırada önemli ders, 3: Üçüncü sırada önemli ders). Bu çalışma kapsamında şu derslerin önemine yönelik velilerin görüşü ele alınmıştır: Beden Eğitimi, Etik, Fen Bilimleri, Matematik, Sanat, Sosyal Bilgiler, Türkçe ve Yabancı Dil.

\section{Veri Analizi}

$\mathrm{Bu}$ çalışmanın veri analizinde regresyon modellerinden lojistik regresyon modeli kullanılmıştır. Lojistik regresyon, bağımlı değişkenin kategorik olduğu durumlarda kullanılan bir analiz türüdür (Mertler ve Reinhart, 2017). Çalışmanın bağımlı değişkeni iki kategoriden oluştuğu için veriler iki kategorili lojistik regresyon ile analiz edilmiştir. Lojistik regresyon analizi uygulamasında, yordayıcı değişkenlerin sıralamasının bir önemi olmadığı için tüm değişkenlerin bir blok olarak regresyon modelinde kullanıldığı standart yönteme başvurulmuştur (Field, 2009).

Araştırmanın bağımlı değişkenini oluşturan kategoriler şunlardır: (a) merkezi sınav başarısı ile ilgili bir dersi birinci sırada önemli görme ve (b) merkezi sınav başarısı ile ilgili olmayan bir dersi birinci sırada önemli görme. Eğer veli, çocuklarının eğitiminde önem derecesine göre ilk sıraya Fen, Matematik, Sosyal Bilgiler, Türkçe ve Yabancı Dil derslerinden birisini yerleştirmişse "Merkezi Sınav Başarısı ile İlgili Olan Bir Dersi Birinci Sırada Önemli Gören Veli” grubunda kodlanmıştır. Eğer veli, Beden Eğitimi, Etik ve Sanat derslerinden 
birisini çocukları için birinci sırada önemli görmüşse "Merkezi Sınav Başarısı ile İlgili Olmayan Bir Dersi Birinci Sırada Önemli Gören Veli” grubunda kategorilendirilmiştir. Araştırmada önerilen model üç kategorik yordayıcı değişkenden oluşmaktadır. Bu değişkenler velinin eğitim düzeyi, gelir seviyesi ve çocuğunun öğretim düzeyidir. Veri analizinde referans kategoriler (0), bağımlı değişken için merkezi sınav başarısı ile ilgili olmayan bir dersi önemli görme olarak belirlenmiştir. Yordayıcı değişkenler için referans kategoriler ise eğitim düzeyi için lise düzeyinin altı, gelir seviyesi için alt gelir grubu $(<3500 \mathrm{TL})$ ve çocuğunun öğretim düzeyi için okul öncesi eğitim düzeyi olarak belirlenmiştir.

Doğrusal regresyon modelleri için gerekli olan varsayımları lojistik regresyon modelinin karşılaması gerekmemektedir (Çokluk, Şekercioğlu ve Büyüköztürk, 2014). Ancak kategorik değişkenlerin kombinasyonu ile oluşan veri matrisinde, her bir hücre için beklenen frekans değerinin en az 5 olması gerekmektedir (Tabachnick ve Fidell, 2014). Bu çalışma için tüm hücrelerde yer alan birey sayısının 5 'ten fazla olduğu belirlenmiştir.

\section{Bulgular}

\section{Betimsel Analiz Sonuçları}

Betimsel analizler ile bu çalışmaya katılan velilerin, belirlenen sekiz ders arasında (Beden Eğitimi, Etik, Fen Bilimleri, Matematik, Sanat, Sosyal Bilgiler, Türkçe ve Yabancı Dil) çocuklarının eğitiminde öncelikli olarak hangi dersi daha önemli gördükleri incelenmiştir. Tablo 2 'de derslerin veliler tarafından birinci sıraya yerleştirilme oranı sunulmaktadır. Velilerin $\% 47.8$ 'i $(n=258)$ Matematik dersini çocukları için en önemli ders olarak seçmiştir. Velilerin $\% 23.7$ 'sine göre $(n=128)$ çocuklarının eğitimde ilk sırada Etik yer almalıdır. Çocukların eğitiminde en önemli görülen ders sıralamasında veliler tarafından en az seçilen üç ders ise sırasıyla Sosyal Bilgiler (\%0.6, $n=3)$, Beden Eğitimi (\%1.5, $n=8)$ ve Sanat'tır (\%3.9, $n=21)$. Bulgular, merkezi sınavlarla ilgili olan bir dersi birinci sırada önemli gören veli sayısının $(n=$ 383, \% 70.9), merkezi sinavlarla ilgili olmayan bir dersi birinci sırada önemli gören veli sayısına ( $n=157, \% 29.1)$ göre önemli ölçüde fazla olduğunu göstermiştir.

Tablo 2. Derslerin Veliler Tarafından Birinci Sırada Önemli Görülmesine İlişskin Betimsel Analiz

\begin{tabular}{lcc}
\hline Ders & $n$ & $\%$ \\
\hline Merkezi Sınav Başarısı ile İlgili Olan Bir Dersi & 383 & 70.9 \\
Birinci Sırada Önemli Görme & & \\
$\quad$ Matematik & 258 & 47.8 \\
$\quad$ Türkçe & 59 & 10.9 \\
Fen Bilimleri & 38 & 7.0 \\
$\quad$ Yabancı Dil & 25 & 4.6 \\
$\quad$ Sosyal Bilgiler & 3 & 0.6 \\
Merkezi Sınav Başarısı ile İlgili Olmayan Bir Dersi & 157 & 29.1 \\
Birinci Sırada Önemli Görme & & \\
$\quad$ Etik & 128 & 23.7 \\
Sanat & 21 & 3.9 \\
$\quad$ Beden Eğitimi & 8 & 1.5 \\
\hline
\end{tabular}


Tablo 3 'te velilerin merkezi sınav başarısı ile ilgili olan ve olmayan bir dersi tercih etme oranları, eğitim düzeyi, gelir seviyesi ve çocuğunun öğretim düzeyi yordayıcı değişkenlerine göre sunulmaktadır. Tablo 3 incelendiğinde merkezi sınav başarısı ile ilgili olmayan bir dersi birinci sırada önemli gören velilerin büyük bir kısmının (\%64) yükseköğretim düzeyinde bir eğitim derecesine sahip olduğu görülmektedir. Merkezi sınav başarısı ile ilgili olan bir dersi daha önemli gören velilerin \%51'i düşük düzeyde gelire sahiptir. Merkezi sınav başarısı ile ilgili olmayan bir dersi birinci sırada önemli gören veliler arasında ortaokul düzeyinde çocuğu olan velilerin oranı (\%19), çocuğu okul öncesi eğitim $(\% 31)$ ve ilkokul düzeyinde (\%51) olan velilerin oranından daha düşüktür. Merkezi sınav başarısı ile ilgili bir dersi birinci sırada önemli gören veliler arasında ise okul öncesi dönemde çocuğu olan veli sayısı en azdır (\%17).

Tablo 3. Velilerin Merkezi Sınav Başarısı ile İlgili Olan ve Olmayan Bir Dersi Birinci Sırada Önemli Görmelerinin Yordayıcılara Göre Betimsel Analizi

\begin{tabular}{|c|c|c|c|c|}
\hline \multirow[t]{2}{*}{ Yordayıcı Değişken } & \multicolumn{2}{|c|}{$\begin{array}{l}\text { Merkezi Sınav Başarısı } \\
\text { ile İlgili Olan } \\
\text { Bir Dersi Birinci Sırada } \\
\text { Önemli Görme }\end{array}$} & \multicolumn{2}{|c|}{$\begin{array}{l}\text { Merkezi Sınav Başarısı } \\
\text { ile İlgili Olmayan } \\
\text { Bir Dersi Birinci Sırada } \\
\text { Önemli Görme }\end{array}$} \\
\hline & $n$ & $\%$ & $n$ & $\%$ \\
\hline \multicolumn{5}{|l|}{ Eğitim düzeyi } \\
\hline Lise altı & 117 & 31 & 24 & 15 \\
\hline Lise & 107 & 28 & 29 & 19 \\
\hline Yükseköğretim & 156 & 41 & 101 & 64 \\
\hline \multicolumn{5}{|l|}{ Aylık gelir seviyesi } \\
\hline Düşük gelir (<3500 TL) & 196 & 51 & 59 & 38 \\
\hline Orta gelir (3501 TL - $5500 \mathrm{TL})$ & 83 & 22 & 42 & 27 \\
\hline Yüksek gelir (> 5501 TL) & 88 & 23 & 47 & 30 \\
\hline \multicolumn{5}{|l|}{ Çocuğunun öğretim düzeyi } \\
\hline Okul öncesi eğitim & 64 & 17 & 48 & 31 \\
\hline İlkokul & 174 & 45 & 80 & 51 \\
\hline Ortaokul & 145 & 38 & 29 & 19 \\
\hline
\end{tabular}

\section{Lojistik Regresyon Analizi Sonuçları}

Velilerin eğitim düzeyi, gelir seviyesi ve çocuğun öğretim düzeyi değişkenleri ile merkezi sınav başarısı ile ilgili olan ve ilgili olmayan bir dersi birinci sırada önemli görmeleri arasındaki ilişki ikili lojistik regresyon analizi ile incelenmiştir. Omnibus testi sonuçlarına göre, sadece sabit terimin yer aldığı başlangıç modeli ile karşılaştırıldığında bu çalışmada önerilen model, velilerin merkezi sınav başarısı ile ilgili olan ve ilgili olmayan bir dersi birinci sırada önemli görme durumunu anlamlı düzeyde daha iyi yordamıştır, $\chi^{2}(6, N=511)=40.43, p=.00$. Başlangıçta 609.589 olan -2LL değerinin 569.164'e düştügü görülmüştür. Hosmer ve Lemeshow ki-kare uyum iyiliği testi de $(p=.861)$ çalışmadaki model-veri uyumunun yeterli düzeyde olduğunu göstermiştir. Çalışmada toplam doğru sınıflandırma oranı \%72 olarak hesaplanmıştır. Ancak önerilen yordayıcıların merkezi sınav başarısı ile ilgili olan bir dersi tercih eden velileri (\%98) merkezi sınav başarısı ile ilgili olmayan bir dersi tercih eden velilere (\%6) göre daha doğru sınıflandırdığ 1 belirtilmelidir. Cox-Snell ve Nagelkerke $\mathrm{R}^{2}$ değerlerine göre, modelde yer alan yordayıcılar veri setinde $\% 8$ ile $\% 11$ arasında bir varyans miktarını açıklamaktadır. Tablo 4 'te önerilen model değişkenlerinin katsayı tahminleri sunulmaktadır. 
Tablo 4. Önerilen Model Değişkenlerinin Katsayı Tahminleri

\begin{tabular}{lccccc}
\hline Yordayıc1 & $\beta$ & $\begin{array}{c}\text { Standart } \\
\text { Hata }\end{array}$ & $\operatorname{Exp}(\beta)$ & Wald & $p$ \\
\hline Velinin eğitim düzeyi & & & & & \\
$\quad$ Lise altı / Lise & -0.15 & 0.33 & 0.862 & 0.204 & .652 \\
$\quad$ Lise altı / Yükseköğretim & $-0.88^{*}$ & 0.32 & 0.417 & 7.390 & .007 \\
$\quad$ Velinin gelir seviyesi & & & & & \\
$\quad$ Düşük gelir / Orta gelir & -0.20 & 0.28 & 0.823 & 0.485 & .486 \\
$\quad$ Düşük gelir / Yüksek gelir & 0.04 & 0.30 & 1.037 & 0.015 & .902 \\
Çocuğun öğretim düzeyi & & & & & \\
$\quad$ Okul öncesi eğitim / İlkokul & 0.43 & 0.25 & 1.544 & 3.040 & .081 \\
$\quad$ Okul öncesi eğitim / Ortaokul & $1.17^{*}$ & 0.30 & 3.215 & 15.493 & .000 \\
\hline
\end{tabular}

Tablo 4'te Wald istatistikleri incelendiğinde velinin gelir seviyesi değişkeninin model üzerinde istatiksel olarak anlamlı düzeyde bir etkisinin olmadığı tespit edilmiştir. Ancak velinin eğitim düzeyi ve çocuğunun öğretim düzeyi, velinin merkezi sınav başarısı ile ilgili olan ve ilgili olmayan bir dersi birinci surada önemli görme durumunu istatistiksel olarak anlamlı düzeyde yordamıştır. Lise düzeyinin altında eğitime sahip olma ile karşılaştırıldığında, yükseköğretim düzeyinde bir eğitime sahip olma velilerin merkezi sınav başarısı ile ilgili olan bir dersi birinci sirada önemli görme odds'unda \%58.3'lük ([1-0.417]*100) bir azalmaya yol açmıştır. Ayrıca, çalışma bulgularına göre velinin çocuğunun okul öncesi eğitime değil ortaokula devam ediyor olmasının, velinin merkezi sınav başarısı ile ilgili olan bir dersi birinci sırada önemli görme odds'unda \%221.5'lik ([1-3.215]*100) bir artışa neden olduğu tespit edilmiştir.

\section{Tartışma ve Sonuç}

$\mathrm{Bu}$ çalışmada ailelerin merkezi sınav başarısı ile ilgili olan ve ilgili olmayan derslere verdikleri önem Sinop ili örneğinde incelenmeye çalışılmıştır. Çalışmaya katılan velilerin çoğunluğu diğer yedi ders ile kıyaslandığında (Beden Eğitimi, Etik, Fen Bilimleri, Sanat, Sosyal Bilgiler, Türkçe ve Yabancı Dil), Matematik dersini çocukları için en önemli ders olarak seçmiştir. Ailelerin çocuklarının akademik başarısını oldukça önemsedikleri (Burgess vd., 2014; Rubie-Davies vd., 2010; Schneider ve Buckley, 2002) göz önünde bulundurulduğunda, bu çalışmada veliler tarafından Matematik dersinin öncelikli olarak önemli görülüyor olması şaşırtıcı bulunmamaktadır. Kadlec, Friedman ve Ott (2007), Amerikalı aileler ile yaptıkları çalışmalarında ailelerin büyük çoğunluğunun üniversite ve iş firsatları açısından çocuklarının fen ile birlikte üst düzey matematik bilgisine sahip olmalarını bir avantaj olarak gördüklerine değinmişlerdir. $\mathrm{Bu}$ çalışmada da velilerin çoğunluğu tarafından Matematik dersinin çocuklar için en önemli ders olarak görülmesi, velilerin Matematik ders başarısını çocuklarının akademik başarısı ve dolayısıyla gelecekteki başarıları için anahtar olarak görmelerinden kaynaklanıyor olabilir.

Diğer taraftan, Matematik dersinden sonra velilerin çoğunluğu tarafından önemli görülen ders Etik olarak tespit edilmiştir. Matematiği önemli gören velilerin oranına kıyasla, Etik dersini önemli gören veli sayısı az olsa da bu bulgu kimi aileler için değerler eğitiminin akademik 
eğitimden daha önemli olduğunu ortaya koymaktadır. Önceki bazı çalışmalarda da ortaya konulduğu gibi (örneğin, Francis ve Archer, 2005; Ryan, vd., 2010), bu bulgu ailelerin okullardan akademik başarı odaklı olmayan bazı beklentileri olduğuna işaret etmektedir. Ailelerin bu beklentileri ile örtüşen değerler eğitimi yenilenen öğretim programlarında yerini almıştır (Milli Eğitim Bakanlığı, [MEB], 2017). Ancak ailelerin etik eğitimine yönelik beklentilerine okulların ve öğretmenlerin uygulamada ne ölçüde cevap verebildiği konusu gelecek araştırmalarda derinlemesine ele alınmalıdır.

Çalışma bulguları, velilerin çoğunluğunun Sosyal Bilgiler, Beden Eğitimi ve Sanat derslerini diğer derslere göre daha az önemli bulduklarını göstermiştir. Şahin ve Toraman (2014) da ilköğretim düzeyinde çocuğu olan ailelerin Müzik dersini önemsemediklerine işaret etmiştir. Bu bulgular ile tutarlı olarak, Türkiye'de yürütülen bazı çalışmalarda akademik başarı baskısından daha uzak olması beklenen okul öncesi eğitim düzeyinde bile kimi aileler tarafından akademik başarı ile ilişkili derslerin daha önemli görüldügü ortaya konulmuştur. Örneğin, Sevimli-Celik, Kirazci ve Ince (2011) beden/hareket eğitimine klyasla matematik ve fen öğretiminin ve Saçkes (2014) sosyal bilgiler ve sanat eğitimine kiyasla okuma ve yazma eğitiminin aileler tarafından daha önemli görüldüğüne dikkat çekmiştir. Türkiye'de ailelerin Beden Eğitimi, Sanat ve Sosyal Bilgiler derslerini daha az önemli görmelerinin nedenlerinden birisi merkezi sınavlarda ağırlığı daha fazla olan derslerin toplum tarafından daha olumlu algılanması (Çetin ve Ünsal, 2018) olabilir. Aileler, bu derslerden elde edilecek başarı ile gelecek başarısı arasında bir ilişki olmadığını düşünüp bu dersleri "işe yaramaz" olarak değerlendirmiş ve sonuç olarak bu dersleri çocuklarının eğitiminde daha az önemli olarak yorumlamış olabilirler. Bu argüman ile tutarlı olarak, Güven ve Öncü (2006) ailelerin çocuklarının beden eğitimi ve spor etkinliklerine katılımının akademik başarılarını olumsuz etkileneceği düşüncesi nedeniyle sıcak bakmadıklarına değinmişlerdir. 2023 Eğitim Vizyonu raporunda kapatılan dershaneler ve halen devam eden özel öğretim kurslarına işaret edilerek Türk Eğitim Sistemi üzerindeki sınav baskısına dikkat çekilmiştir (MEB, 2018). Bu raporda öğrenmenin iyileştirilmesi için ortaöğretime ve yükseköğretime geçişte yarışmaya ve elemeye dayalı çoktan seçmeli sınavların azaltılması gerektiği belirtilmiştir. Yeni eğitim vizyonumuzda öğrencilerin sosyal, kültürel ve sportif etkinliklere katılımının izleneceğinin belirtilmesi, aileler tarafından merkezi sınav başarısı ile ilgili olmayan derslere verilen değerin artmasına neden olabilir.

Beklenti-değer teorisine göre çocukların ailelerinin daha önemli gördükleri etkinliklere ve derslere katılmaya daha istekli oldukları (Eccles, 2005; Eccles ve Wigfield, 2002; Wigfield ve Eccles, 2000) göz önünde bulundurulduğunda, Türkiye'de ailelerin Sosyal Bilgiler, Beden Eğitimi ve Sanat derslerini öncelikli olarak önemsemiyor olmaları çocukların bu alanlara ilgi duymalarını ve bu alanlarda kendilerini geliştirmelerini engelleyebilir. Çocuklar bu alanlara ilgi duysalar bile, ailelerinin etkisiyle ve belki de ailelerini memnun etmek için ailelerinin daha önemli gördükleri alanlara yönelebilirler. Sosyal Bilgiler, Beden Eğitimi ve Sanat alanlarına özel ilgisi olan fakat bu ilgiyi önemli bulmayan ailelere sahip çocukların kendilerini bu alanlarda geliştirebilmeleri hususunda desteğe ihtiyaçları olabilir. Çocukların ilgi duydukları ve yetenekli oldukları alanlarda desteklenmelerinin önemi hususunda Türkiye'de ailelerde bir farkındalığın geliştirilmesi sağlanmalıdır. Benzer şekilde, Kahraman (2014) çalışmasında görsel sanatlar dersinin önemsenmiyor oluşuna dikkat çekerek bu dersin önemine ilişkin velilerin ve çocukların bilinçlendirilmelerini önermiştir. 
Ailelerin önem verdiği derslere ilişkin bulguların yorumlanmasında bir hususa dikkat edilmelidir. Bu çalışmada pek çok aile Sosyal Bilgiler, Beden Eğitimi ve Sanat derslerini birinci sırada önemli görmemiştir. Ancak bu durum, bu ailelerin bu dersleri hiç önemli görmedikleri şeklinde yorumlanmamalıdır. Atan, Eliöz ve Polatcan (2014) ailelerin Beden Eğitimi dersine karşı olumlu bir tutuma sahip olduklarını bulmuşlardır. Pehlivan (2009) bazı ailelerin çocuklarının spor etkinliklerine katılımını önemsediğini ve desteklediğini göstermiştir. Bu çalışmaya katılan aileler de Sosyal Bilgiler, Beden Eğitimi ve Sanat derslerine karşı olumlu bir tutuma sahip olabilirler ancak bu dersleri Matematik, Etik, Türkçe, Fen Bilimleri ve Yabancı Dil dersleri ile karşılaştırıldığında daha az değerli bulmaktadırlar. Ailelerin bazı dersleri daha önemli görme nedenleri sonraki araştırmalarda derinlemesine incelenmelidir.

Önemli olarak, bu çalışma ailenin eğitim düzeyi ve çocuğun öğretim düzeyi ile velinin merkezi sınav başarısı ile ilgili olan ve ilgili olmayan bir dersi birinci sırada önemli görmesi arasında anlamlı bir ilişki olduğunu göstermiştir. Ailenin eğitim düzeyine ilişkin olarak, Schneider vd.'nin (1998) ve Saçkes'in (2014) bulguları ile örtüşen şekilde, bu çalışma lisenin altında bir eğitim derecesine sahip olan veliler ile karşılaştırıldığında, yükseköğretim düzeyinde bir eğitim derecesine sahip olan velilerin merkezi sınav başarısı ile ilgili olmayan bir dersi daha önemli görme eğiliminde olduklarını göstermiştir. Bu bulgu daha eğitimli ailelerin çocuklarının başarısını akademik/okul başarısı odaklı değerlendirmedikleri şeklinde yorumlanabilir. Yükseköğretim derecesine sahip ailelerin daha bilinçli olacakları varsayılırsa, bu aileler Türk Ĕ̆itim Sistemi'nin çocukları üzerinde yarattığı sınav baskısına bir tepki olarak sınav odaklı olmayan dersleri çocukları için daha önemli olarak değerlendirmiş olabilirler. Çocuğun öğretim düzeyi ile ilgili olarak, çocuğu okul öncesi eğitime devam eden veliler ile karşılaştırıldığında, çocuğu ortaokula devam eden velilerin merkezi sınav başarısı ile ilgili olan bir dersi birinci sırada önemli gördükleri tespit edilmiştir. Bu bulgu Türk Eğitim Sistemi’nde öğretim düzeyi arttıkça çocuklar ve aileleri üzerinde sınav baskısının arttı̆̆ını göstermektedir.

Alanyazında ailenin gelir seviyesi ile çocuklarının eğitiminde neleri önemli gördükleri arasında bir ilişki olduğuna dikkat çeken çalışmalara rastlanmaktadır (örneğin, Jacob ve Lefgren, 2007; Kıldan, 2013; Saçkes, 2013). Ancak bu çalışmada gelirin tek başına anlamlı bir etkisinin olmadığı bulunmuştur. Bu çalışmada örneklem çocuklarını devlet okuluna gönderen velilerden oluştuğu için bu etki ortaya çıkmamış olabilir. Gelecek çalışmalarda aile gelir seviyesinin ailelerin derslere yönelik görüşlerini nasıl etkilediği araştırılırken çocuklarını özel okula gönderen velilerin de araştırmaya dahil edilmesi düşünülmelidir. Eccles (2005) eğitim geçmişi, üyesi olunan kültür ve meslek gibi faktörlerin ailelerin görüşlerini etkilediğini ortaya koymuştur. Bundan yola çıkarak, gelir ile ilişkili olmayan bazı aile özelliklerinin ailelerin çocuklarının eğitimine ilişin görüşleri üzerinde daha etkili olduğu ileri sürülebilir.

$\mathrm{Bu}$ araştırmanın örneklemi Türkiye'nin Sinop ilinde yaşayan veliler ile sınırlıdır. Türkiye'nin farklı illerinde yaşayan velilerin oluşturduğu örneklemlerle bu çalışmanın tekrarlanmasına ihtiyaç duyulmaktadır. Alanyazında velilerin çocuklarının eğitiminde verdikleri önemi etkileyen faktörler arasında kültürel yapı, anne-baba olarak üstlenilen rol ve çocuklarının cinsiyeti yer almaktadır. Gelecek çalışmalarda bu değişkenlerin ele alınması önemli görülmektedir. Bu çalışmada çocuğun öğretim düzeyi ile velinin merkezi sınav başarısı ile ilgili olan ve ilgili olmayan bir dersi önemli görmesi arasında istatistiksel olarak anlamlı bir ilişki olduğu bulunmuştur. Sonraki çalışmalarda, velilerin derslere verdikleri önem çocuklarının 
eğitim hayatı boyunca yıldan yıla ölçülmeli ve veli görüşlerinin çocuklarının farklı öğretim düzeylerinde nasıl bir değişim gösterdiği boylamsal olarak araştırılmalıdır. 2023 Eğitim Vizyonu ile merkezi sınav başarısı ile ilgili olmayan dersler ön plana çıkarılacaktır. Dolayısıyla Türk Eğitim Sistemi’nde gerçekleşen değişikliklerin velilerin çocuklarının eğitimine yönelik görüşleri üzerindeki etkisine ilişkin çalışmalar yürütülmelidir. Velilerin görüşlerine ilişkin elde edilen nicel çalışma bulgularını açıklamaya yönelik nitel araştırmalar yapılmalıdır. Bu çalışma veli raporları ile sınırlıdır. Gelecek araştırmalarda, veri kaynağını çeşitlendirmek amacıyla öğretmen ve öğrenci görüşleri de çalışmalara dahil edilmelidir.

Çocukların Ĕ̆itiminde Merkezi Sınav Başarısı ile İlgili Dersler Daha mı Önemli? Aile Görüşü ve İlişkili Faktörler başlıklı çalışmanın yazım sürecinde bilimsel, etik ve alıntı kurallarına uyulmuş; toplanan veriler üzerinde herhangi bir tahrifat yapılmamış, karşılaşılacak tüm etik ihlallerde "Pamukkale Üniversitesi Eğitim Fakültesi Dergisi Yayın Kurulunun" hiçbir sorumluluğunun olmadığı, tüm sorumluluğun Sorumlu Yazara ait olduğu ve bu çalışmanın herhangi başka bir akademik yayın ortamına değerlendirme için gönderilmemiş olduğunu taahhüt ederim. 


\section{Kaynakça}

Achhpal, B., Goldman, J. A., \& Rohner, R. P. (2007). A comparison of European American and Puerto Rican parents' goals and expectations about the socialization and education of pre-school children. International Journal of Early Years Education, 15(1), 1-13.

Archer, L., DeWitt, J., Osborne, J., Dillon, J., Willis, B., \& Wong, B. (2013). "Not girly, not sexy, not glamorous": Primary school girls' and parents' constructions of science aspirations. Pedagogy, Culture \& Society, 21(1), 171-194.

Atan, T., Eliöz, M. ve Polatcan, İ. (2014). Farklı bölgelerde yaşayan velilerin çocuklarının beden eğitimi dersine katılımından beklentileri. Erzincan Üniversitesi Ĕgitim Fakültesi Dergisi, 16(1), 57-74.

Bronfenbrenner, U. (1979). The ecology of human development: Experiments by nature and design. Cambridge, MA: Harvard University Press.

Bronfenbrenner, U. (1986). Ecology of the family as a context for human development: Research perspectives. Developmental Psychology, 22(6), 723-742.

Burgess, S., Greaves, E., Vignoles, A., \& Wilson, D. (2014). What parents want: School preferences and school choice. The Economic Journal, 125(587), 1262-1289.

Coldron, J., \& Boulton, P. (1991). "Happiness" as a criterion of parents' choice of school. Journal of Education Policy, 6(2), 169-178.

Curry, K. A., \& Holter, A. (2019). The influence of parent social networks on parent perceptions and motivation for involvement. Urban Education, 54(4), 535-563.

Çetin, A. ve Ünsal, S. (2018). Merkezi sınavların öğretmenler üzerinde sosyal, psikolojik etkisi ve öğretmenlerin öğretim programı uygulamalarına yansıması. Hacettepe Üniversitesi Ĕ̈itim Fakültesi Dergisi, [Çevrim-içi: http://www.efdergi.hacettepe.edu.tr/upload/files/2826published.pdf], Erişim tarihi: 26.03.2019.

Çokluk, Ö., Şekercioğlu, G. ve Büyüköztürk, Ş. (Ed.). (2014). Sosyal bilimler için çok değişkenli istatistik: SPSS ve LISREL uygulamaları (3. Bask1). Ankara: Pegem Akademi.

Davis-Kean, P. E. (2005). The influence of parent education and family income on child achievement: The indirect role of parental expectations and the home environment. Journal of Family Psychology, 19(2), 294-304.

Eccles, J. S. (2005). Influences of parents' education on their children's educational attainments: The role of parent and child perceptions. London Review of Education, 3(3), 191-204.

Eccles, J. S., \& Wigfield, A. (2002). Motivational beliefs, values, and goals. Annual Review of Psychology, 53(1), 109-132.

Epstein, J. L. (1986). Parents' reactions to teacher practices of parent involvement. The Elementary School Journal, 86(3), 277-294.

Field, A. (2009). Discovering statistics using SPSS (and sex and drugs and rock ' $n$ ' roll) (3rd ed.). London: Sage Publications.

Fraenkel, J. R., \& Wallen, N. E. (2006). How to design and evaluate research in education. New York: McGraw Hill.

Francis, B., \& Archer, L. (2005). British-Chinese pupils' and parents' constructions of the value of education. British Educational Research Journal, 31(1), 89-108.

Galper, A., Wigfield, A., \& Seefeldt, C. (1997). Head Start parents' beliefs about their children's abilities, task values, and performances on different activities. Child Development, 68(5), 897-907.

Güven, Ö. ve Öncü, A. G. E. (2006). Beden eğitimi ve spora katılımda aile faktörü. Sosyal Politika Çalışmaları Dergisi, 10(10), 81-90.

Halle, T., Kurtz-Costes, B., \& Mahoney, J. (1997). Family influences on school achievement in low income, African American children. Journal of Educational Psychology, 89(3), 527-537.

Hoover-Dempsey, K. V., \& Sandler, H. M. (1995). Parental involvement in children's education: Why does it make a difference? Teachers College Record, 97(2), 310-331. 
Jacob, B. A., \& Lefgren, L. (2007). What do parents value in education? An empirical investigation of parents' revealed preferences for teachers. The Quarterly Journal of Economics, 122(4), 1603-1637.

Kadlec, A., Friedman, W., \& Ott, A. (2007). Important, but not for me: Parents and students in Kansas and Missouri talk about math, science and technology education. [Çevrim-içi: https://files.eric.ed.gov/fulltext/ED498649.pdf], Erişim tarihi: 11.04.2019.

Kahraman, D. (2014). Sınıf öğretmenlerinin görsel sanatlar dersi programının uygulanmasında karşılaşılan sorunlara ilişkin görüşleri ve çözüm önerileri. Abant İzzet Baysal Üniversitesi Ĕgitim Fakültesi Dergisi, 14(1), 221-240.

Kildan, A. O. (2013). Analysis of the expectation levels of the parents from the preschool education institution in terms of various variables. International Journal of Educational Research and Technology, 4(1), 6-12.

Mertler, C. A., \& Reinhart, R. V. (2017). Advanced and multivariate statistical methods: Practical application and interpretation (6th ed.). London: Routledge.

Milli Eğitim Bakanlığı. (2017). Müfredatta yenileme ve değişiklik çalışmalarımız üzerine. [Çevrim-içi: http://ttkb.meb.gov.tr/meb iys dosyalar/2017 07/18160003 basin aciklamasi-program.pdf], Erişim tarihi: 19.04.2019.

Milli Eğitim Bakanlığı. (2018). 2023 Eğitim Vizyonu. [Çevrim-içi: http://2023vizyonu.meb.gov.tr/doc/2023_EGITIM_VIZYONU.pdf], Erişim tarihi: 19.03.2019.

Nacak, M., Yağmurlu, B., Durgel, E., \& van de Vijver, F. (2011). Metropol ve Anadolu'da ebeveynlik: Biliş ve davranışlarda şehrin ve eğitim düzeyinin rolü. Türk Psikoloji Dergisi, 26(67), 85-100.

Neuenschwander, M. P., Vida, M., Garrett, J. L., \& Eccles, J. S. (2007). Parents' expectations and students' achievement in two western nations. International Journal of Behavioral Development, 31(5), 594-602.

Okagaki, L., \& Sternberg, R. J. (1993). Parental beliefs and children's school performance. Child Development, 64(1), 36-56.

Pehlivan, Z. (2009). Spora katılan çocuklara yönelik ailelerin beklentileri, çocuklarda gözlenen davranış değişimleri ve spora katılımın önündeki engeller. Spormetre Beden Eğitimi ve Spor Bilimleri Dergisi, 7(2), 69-76.

Rubie-Davies, C. M., Peterson, E., Irving, E., Widdowson, D., \& Dixon, R. (2010). Expectations of achievement: Student teacher and parent perceptions. Research in Education, 83(1), 36-53.

Ryan, C. S., Casas, J. F., Kelly-Vance, L., Ryalls, B. O., \& Nero, C. (2010). Parent involvement and views of school success: The role of parents' Latino and White American cultural orientations. Psychology in the Schools, 47(4), 391-405.

Saçkes, M. (2013). Erken çocukluk eğitiminde önem verilmesi gereken gelişimsel alanlar: Anne-baba ve öğretmen önceliklerinin karşılaştırılması. Kuram ve Uygulamada Ĕ̈itim Bilimleri Dergisi, 13(3), 1675-1690.

Saçkes, M. (2014). Parents who want their Pre-K children to have science learning experiences are outliers. Early Childhood Research Quarterly, 29(2), 132-143.

Schneider, M., \& Buckley, J. (2002). What do parents want from schools? Evidence from the Internet. Educational Evaluation and Policy Analysis, 24(2), 133-144.

Schneider, M., Marschall, M., Teske, P., \& Roch, C. (1998). School choice and culture wars in the classroom: What different parents seek from education. Social Science Quarterly, 79(3), 489-501.

Senler, B., \& Sungur, S. (2009). Parental influences on students' self-concept, task value beliefs, and achievement in science. The Spanish Journal of Psychology, 12(1), 106-117.

Sevimli-Celik, S., Kirazci, S., \& Ince, M. L. (2011). Preschool movement education in Turkey: Perceptions of preschool administrators and parents. Early Childhood Education Journal, 39(5), 323333 
Simpkins, S. D., Fredricks, J. A., \& Eccles, J. S. (2012). Charting the Eccles' expectancy-value model from mothers' beliefs in childhood to youths' activities in adolescence. Developmental Psychology, 48(4), 1019-1032.

Spera, C., Wentzel, K. R., \& Matto, H. C. (2009). Parental aspirations for their children's educational attainment: Relations to ethnicity, parental education, children's academic performance, and parental perceptions of school climate. Journal of Youth and Adolescence, 38(8), 1140-1152.

Sunar, D., \& Okman-Fişek, G. O. (2005). Contemporary Turkish families. In U. Gielen, \& J. Roopnarine (Eds.), Families in global perspective (pp.169-183). New York: Allyn \& Bacon/Pearson.

Şahin, A. ve Toraman, M. (2014). İlköğretim müzik dersine yönelik veli ve öğrenci görüşleri. Abant İzzet Baysal Üniversitesi Eğitim Fakültesi Dergisi, 14(1), 329-345.

Tabachnick, B. G., \& Fidell, L. S. (2014). Using multivariate statistics (6th ed.). Boston, MA: Allyn \& Bacon.

Wentzel, K. R. (1998). Parents' aspirations for children's educational attainments: Relations to parental beliefs and social address variables. Merrill-Palmer Quarterly, 44(1), 20-37.

Wigfield, A. (1994). Expectancy-value theory of achievement motivation: A developmental perspective. Educational Psychology Review, 6(1), 49-78.

Wigfield, A., \& Eccles, J. S. (2000). Expectancy-value theory of achievement motivation. Contemporary Educational Psychology, 25(1), 68-81. 


\section{Extended Abstract}

The expectancy-value theory of academic motivation (Wigfield, 1994; Wigfield \& Eccles, 2000) asserts that parents exert a decisive role in the education of their children. Based on this theory, Eccles (2005) argues that parents' task values influence children's beliefs for these tasks, which eventually affects children's involvement and success in them. In relation to parental influence on children, it should be noted that children may participate in activities just to please their parents (Eccles \& Wigfield, 2002). Given the impact of parents on children's motivation and actions, it becomes imperative to comprehend what parents believe to be important in the education of their children. To shed light on some aspects of parental beliefs about education in the context of Turkey, the present study examines how important Turkish parents perceive school courses that are related (Science, Mathematics, Social Studies, Turkish, and Foreign Language Education) and not related (Physical Education, Ethics, Art) to central exam success. The study especially scrutinizes if parents' educational degree and income level and their children's level of education are related to parents' rating of a subject that is related and not related to central exam success in the first place.

The sample of this study involved 540 parents whose children were attending public schools in the central districts of Sinop province, a small non-metropolitan city in the north region of Turkey. In the sample, respondents were mostly mothers (66.3\%). Of the sample, $47.6 \%$ had a higher education degree, while the remaining had either a high school degree $(25.2 \%)$ or a degree below high school (26.1\%). Considering the income level, $47.2 \%$ of the parents had a low income level $(<3500$ Turkish Lira). On the other hand, $23.1 \%$ had a medium level of income (between 3501 and 5500 Turkish Lira) and 25\% had a high level of income (> 5501 Turkish Lira). The parents had children attending three different levels of education. Namely, $20.7 \%$ was the parents of preschool children, $47 \%$ was the parents of elementary school children, and $32.2 \%$ was the parents of middle school children. In the study, data were collected through a questionnaire developed by Saçkes (2014). This questionnaire was intended to be used with the parents of preschool children. Minor revisions were made in the content of the questionnaire so that it would be appropriate for the parents of elementary and middle school children in addition to the parents of preschool children. The revised questionnaire was reviewed by two experts and piloted with six parents. The parents were asked the following main question: "Which of the following subjects should be primarily addressed in your child's class?" The subjects parents were asked to order according to their importance from 1 to 3 (1: The most important subject for education of their children, 2: The subject important for the education of their children in the second place, 3: The subject important for the education of their children in the third place). The subjects addressed in this study included Physical Education, Ethics, Science, Mathematics, Art, Social Studies, Turkish, and Foreign Language Education. Descriptive statistics and logistic regression analysis were used in data analysis.

The descriptive results indicated that most parents rated Mathematics $(47.8 \%, n=258)$ as the most important subject for the education of their children. Previous literature has evidenced that parents consider academic achievement important for their children to have a good future (e.g., Burgess, Greaves, Vignoles, \& Wilson, 2014; Rubie-Davies, Peterson, Irving, Widdowson \& Dixon, 2010; Schneider \& Buckley, 2002). Thus, the selection of Mathematics as the most important subject in the current study might be because parents link children's success in 
Mathematics with high academic achievement and so with a better life in future. Remarkably, $23.7 \%$ of the parents $(n=128)$ selected Ethics as the most important subject for their children in the study. This finding indicates that some parents care more about their children's being good persons than being successful persons. Only few parents viewed Social Studies $(0.6 \%, n=3)$, Physical Education $(1.5 \%, n=8)$, and Art $(3.9 \%, n=21)$ as the most important subject for their children. The parents were less likely to prioritize these subjects maybe because of the central exam pressure experienced in Turkish Education System. The 2023 Education Vision Report suggests that the central exams based on competition and elimination should be quitted and children should be provided with more opportunities for involving in social, cultural, and sport activities in schools (Ministry of National Education, 2018).

The logistic regression analysis showed that there was a significant relationship between the parents' perception of the importance of a subject that is related or not related to central exam success and parents' degree of education and their children's level of education. Specifically, the parents with a higher education degree were more likely to rate a subject that is not related to central exam success (i.e., Physical Education, Ethics, Art) in the first place. As we expect parents with a higher education degree to be more conscious of their children's needs and interests, they might be more likely to value tasks that reduce the pressure of central exams on their children. The study indicated that the parents of middle school children were more likely to rate a subject in the first place if it is related to central exam success (i.e., Science, Mathematics, Social Studies, Turkish, and Foreign Language Education). This is not a surprising finding considering that parents and so children are more concerned about preparing for exams in middle schools to be eligible for attending a high-quality high school and consequently a high-quality college in the future. The current study should be replicated with samples drawn from different regions of Turkey to yield more generalizable results. This study investigated the parental values regarding different school subjects, but it did not unveil the reasons behind parents' choice of the subjects. This gap can be addressed with future qualitative studies. 